\title{
Liberal Humanism and Its Effect on the Various Contemporary Educational Approaches
}

\author{
Zargham Yousefi $^{1}$, Alireza Yousefy ${ }^{2} \&$ Narges Keshtiaray ${ }^{1}$ \\ ${ }^{1}$ Department of Educational Sciences, Isfahan (Khorasgan) Branch, Islamic Azad University, Isfahan, Iran \\ ${ }^{2}$ Medical Education Research Centre, Isfahan University of Medical Sciences, Isfahan, Iran \\ Correspondence: Alireza Yousefy, Medical Education Research Centre, Isfahan University of Medical Sciences, \\ Isfahan, Iran. E-mail: ar.yousefy@gmail.com
}

\author{
Received: October 16, 2014 Accepted: November 20, 2014 Online Published: February 25, 2015 \\ doi: $10.5539 /$ ies.v8n3p103 \\ URL: http://dx.doi.org/10.5539/ies.v8n3p103
}

\begin{abstract}
Liberalism is one of the main western doctrines which have originated from the ideologies of ancient Greece. The concept of humanism has been under the influence of liberal ideas in different political, social, economic and especially educational field. Since the educational field concerned with liberal ideologies, the study of different factors affecting liberal humanism helps distinguishing the concepts explained by each approaches and their similarities and differences. In this qualitative research, it has been endeavored to determine each of these aspects and factors and their effect on various contemporary educational approaches. The results indicate that some of the main factors of liberal humanism have not been considered and in the cases that they have been considered, the understandings of common subjects are different. Each of these approaches tends to study and define the aspects and principles from a certain point of view.
\end{abstract}

Keywords: liberalism, humanism, education, contemporary educational approaches

\section{Introduction}

\subsection{The Concept of Liberalism}

Liberalism is known as a combination of methods, thoughts, and policies with the aim of providing individuals with the upmost freedom and liberation possible (Bring, 2008). Liberalism is a concept based on individualism, therefore, benefits in this accordance, it is notable to mention that restraining the liberations is in no way acceptable, since all of the problems are caused by such limitations caused by the government or any other educational center which threaten individuals and their liberation. These limitations are the regulations set, which limit one's liberties, especially in the field of economics which eventually leads to corruption (Pring, 2009).

In accordance with liberalism, it can be stated that in spite of its historical flexibility, it has remained as an intact approach throughout time; an approach which main compartments are comprehendible without much difficulty. For this reason, we are able to consider John Locke, Emanuel Cunt, John Stewart Mill, Hebret Spencer, John MinardKinz, Fredrich Von Hyke, and John Riles Robert Nazik as different branches of one common subject. According to the American Scientific Progression Association, liberal education informs small letter individuals or those who have dogmatic ideologies of the various other existing ideologies and nurtures the results of such thoughts in the actual natural world and in their conscience and subconscious (Project on liberal education and the sciences, 1990). Liberal education, in fact, combines traditional education with literal, humane educations and ethical values. Such teachings help individuals to face their problems in life with more ease

Liberal education provides a great opportunity for the members of a society to become literate and thoughtful citizens. Herst (1965) explained that the basis of liberal education is obtaining knowledge and science. He insists that there is a logical relevance between the concepts of logic and knowledge. Knowledge acquisition is necessary for the growth and development of the mind Herst (1965). In his opinion, the most important common factors in liberalism are: 1) Liberty: the right to live, liberty of thought, idea, logic, opinion, religion, expression, media, gatherings and that of economic liberties; 2) The dominance of individuals in relevance with their society; 3) Equality in formation and civil rights or equality in rights; 4) Tolerance of adversaries or simplification; 5) The dominance of regulations or legalism; 6) Limited or conditional government; 7) The dominance of logic and 
science as the basis of performance; and 8) Mundane progression based on technology.

Of the other important principles of liberalism, one may point to privacy in people's lives, secularism and democracy, the basis of all being man himself. In Figure 1, the relationship of the liberal humanization has been shown:

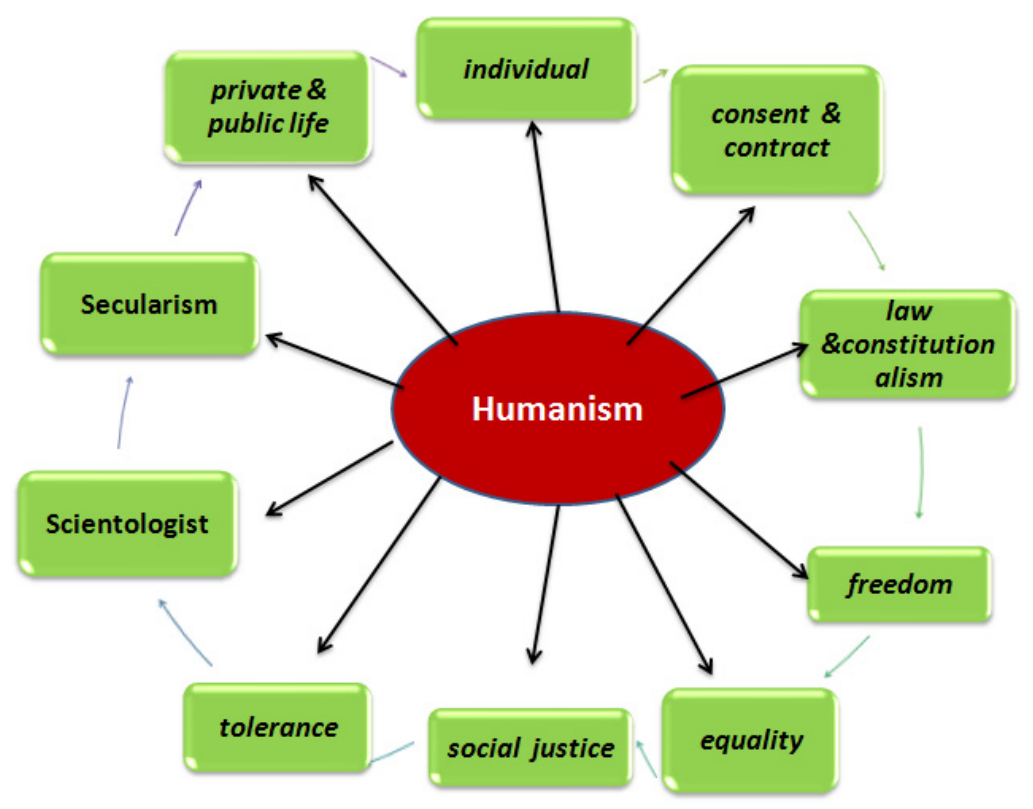

Figure 1. The relationship between liberal humanism

\subsection{The History of Liberal Education}

Liberal ideologies have a long background in the western history. Axelrod and Ansin Wilin believe that liberal education runs its roots in the theologies of that of ancient Greece. The traces of this assumption can be seen in the works of Socrates (470-399 BC) and in the history of ancient Rome and the works of Peter Abelard (1077-1142) in the middle ages. In spite of the factors which forming the definitive mode of liberal ideologies did not emerge until the renaissance and when they did, they did so in the form of the works of Erasmus, Decarte and Milton. Ulich (1968) finds Aristotle's approach considering moderation and balance, close to liberal tendencies. The relevance between wisdom and moderation is the same as the relevance between knowledge and performance, which is constantly repeated in liberal education. Studies indicate that liberal educations are widely various, general, and at times, paradoxical. The slave societies in the past time consisted of slaves and free (liberal) members. Most liberal members feared the loss of their liberty, since they would no longer be able to benefit from any right, including that of citizenship, education, occupation and in a way, would be from the society. In those very same ages, Socrates emphasized the importance of individualism in societies and taught his pupils that as individuals, they must have their own ideas and opinions and express and employ them (Clark, 2008).

When liberal teachings were obsolete in the Middle Ages by barbarians, they emerged once again, simultaneously, with the reappearance of Socrates' theories in the eleventh and twelfth centuries. In the thirteenth and fourteenth centuries, rebellions against religious partiality took place which resulted in teachers focusing on man himself rather than God. The main reasons behind such movements and changes are the tendency of mankind towards nature and aesthetics (Brady, 2009).

The study of classic and humanitarian theories dates back to the fourteenth century, due to the increase in the studies of roman books and literature. In the fifteenth and sixteenth centuries, liberal education was focused on classic teachings. Since normal people did not possess the required knowledge to study such theories, they should have been taught in a simplified and understandable form. In the later years of the twentieth century, both the humanitarians and the classicists were affected by liberal teachings, and nurtured their logic and philosophy with their help (Paton, 2004). Although liberal teachings are considered as a western movement, it has left its impact all around the globe. It is also of importance to mention that liberal approaches concerning the 
educational field can be found and traced in that of the Greek philosophers (Zibakalam, 1993). The more evident form of liberal ideologies was presented in the nineteenth century, which is also known as the century of enlightening. Liberalism was a title given to the ideas which remained from the philosophers of the enlightening age, such as Walter, Russo and Montsico in France, Locke, Hume, and Adam Smith in Britain, Gute and Cunt in Germany and Jefferson and Franklin in the United States.

\subsection{Liberal Humanism}

Humanism is an approach which focuses on man's abilities and his troubles in the form of empirical experiments, social studies, philosophical research and artistic creations. Humanism is a repetitive cultural-ideological movement with the purpose of creating motivation and a new-found tendency towards important roman and Greek works. Humanism, democracy, human gentility or human manifestation are doctrines which put man in the center of the universe and deprives God and religion or any other non-human phenomena of originality and authenticity, by giving man that very same attribute. This means that man is in the center of attention in all philosophical, political, economic, ethical, or social systems. Humanism considers man as the only truth and reality in creation and places him in the throne of God, and instead of Him. Humanism is, in fact, worshipping man (Muir, 2005).

Therefore, humanism is the liberal approach to man. In this doctrine, unlimited and unrestrained freedom leads to a successful and regulated lifestyle, because man is sane and will not lead his life astray and towards oblivion. One of the main flaws of liberalism is the uni-dimensional, incomplete and one-sided approach to man and his complicated nature (Curriculum Development Center, 2007, pp. 143-145).

In modern liberalism, man is his own and the universe's savior, who does so by relying on his logic and is needless of God or any other divine being. As the modern philosopher, Ayziaberlin states "what our age needs is not stronger faith, but in actuality, the opposite of it. In modern liberalism, all materialistic pleasures, even those which are loathsome, are considered of high importance, due to the reason that in this doctrine, all that passes the mind is of considered so (Walers, 1995). The most important principles of humanism are: 1) Human orientation ( $\operatorname{man}$ is the scale to all that exists and is also the center and the supreme possessor of all creation. The valuation of everything should be done by him.) 2) Liberty (he has been entitled to power and it is he who determines his fate). 3) Logic (human logic is the leader of mankind. Humanism logic is self-manifested and needless of revelation). 4) Naturalism (nature is man's domain and he can obtain connections with nature, by his senses.) 5) Tolerance (by giving man authenticity, all humane ideas and actions will be of value) (Coates, 2009).

The importance of the factors relating to liberal humanism in contemporary educational approaches.

\section{Freedom}

The most important aspect of liberalism is freedom. In liberalism, freedom is not an instrument in achieving higher political goals, but is, in fact, the highest political aim. Liberals make great emphasis on freedom, especially that of thought. For instance, Stewart Mill writes: "if man is not free, does not live freely, and does not pick the path he wishes to tread, progression is impossible and until ideas are presented freely and publicly, the veils of lies will not fall" in Berlin (2001).

In Stanford's philosophical encyclopedia, Russo is mentioned as one of the pioneers of positive freedom. According to this narrative, it was the philosophers and modernists of the later years of the nineteenth and the beginning years of the twentieth century, such as Thomas Hill Green, who based the main structure of this approach. (Stanford's Encyclopedia of Philosophy, 2010). From another approach, negative freedom is based on the dominance of freedom on every other issue, such as justice and truth. The dominance of freedom is based on the goodness of human nature. In his book "Regulations", Plato states that a free man, is someone who has the behavior and thought of a philosopher. A philosopher is a person who has the freedom and ability to choose between various options and has complete control on his life and judgments, knows how to adjust himself with various situations and, therefore, is a happy and successful individual (Gosling, 1973).

In accordance with freedom in contemporary approaches, various definitions have been presented by each and every one of them. From the aspect of the analytical approach, freedom is explained so: when one has various options and choices he or she is able to choose between them intelligently and knowingly and after that, acts accordingly with the decision that they have made. In this approach, free will and responsibility are closely related (same source). While the existentialism approach studies the matter differently. According to this approach, man is responsible for his thoughts and actions. This responsibility is corollary to his freedom. However, in the main issue, the existence of freedom is already assumed. Sartre believes that man is doomed to build humanity with no help, and in every moment that passes. Therefore in this approach, not only is man free, 
he is fated and doomed to this fate. Man is naturally born free and should retain this freedom throughout his life. If one is unable of doing so, he has exited the domain of authentic humanity. Existentialist philosophers emphasize the point of human individualism and his relevance with the world around him.

From the aspect of pragmatism, which runs its roots in the Russoian method of thought, freedom is explained as follows: each person has some abilities and talents and it is one of the many rights of children to employ and improve them. They should be allowed to develop these talents (Gutek, 2007). Therefore, in schools and educational centers, circumstances and conditions, such as computers, educational equipment and teachers, are provided, in order to aid them in this task (Shariatmadari, 2005, p. 25). In Dioie's opinion, the only freedom is the freedom of logic. This freedom is only achieved when one is able to examine and assess different circumstances and options, determine valuable and important goals for himself and employs various instruments which may aid him in attaining the goals mentioned (Gutek, 2007).

Frankfurth as a critical approach towards the issue of freedom by arguing that the economic approach status of human societies improves, freedom loses its validity and original meaning. According to Marcuse the development of human society is always changing, and in today's societies, is free to do whatever the need of this life makes him to and has leaded him to such alienation. From this approach, understanding any form of freedom is in need of understanding the forms of slavery related to it. The biggest mistake is that people nowadays do not concern themselves with the issues of slavery and freedom, due to the fact that providing for life's needs is considered to be more importance compared with such issues. This is because that "choice" and ability to choose are not the only aspects of freedom. Truly benefitting from freedom is only possible if one has the ability to understand how to choose and to assess what he has to choose. Therefore, not all decision makings are considered a result of freedom (Marcuse, 2004, pp. 37-43).

All in all, it can be concluded that from analytic approach, a strong relationship exists between freedom and responsibility, whilst in the existentialism approach, responsibility is considered an outcome of freedom, and freedom is considered an internal principle. From another perspective, pragmatic philosophers have chosen to follow Russo's view. This means that man has to be free to develop his talents. Frankfurt's approach is different from all that is mentioned, and claims that freedom has taken a creditable form in today's societies, therefore, decision making, in itself, is not considered freedom and aspects such as the procedure of choosing and assessing what should be chosen should be taken into consideration.

\section{Individualism}

The concept of individual emphasizes a single person. An individual is the first and the last concern of liberalism; the first, because an individual's rights are based on the natural state, a state which he has no other option but to change nature to his own accord; the last, because individuals are production units. In liberalism, individuals are regarded without concerning their race, group, society, religion, and the party that they have joined. He is regarded as a person in the possession of natural rights. From one approach, individualism means that each human has a private mental and physical domain, opinion and other fundamental rights which are to be honored under all circumstances (Meiksins, 1972). Individualism places individuals as its centre point of attention and begins the fundamental basis that an individual is of great importance in his struggle for freedom. Therefore, individualism is the right of an individual for their freedom and the developing their talents (Lapsey, 1988). Individualism has had noticeable and different dimensions in modern educational approaches. In analytic philosophy, individualism cannot be derived and defined separately from the society that it in ind the issues of individualism and socialism are considered as the two sides of one coin. Tin contrast individualism has a completely independent meaning in the approach of existentialism and is considered as one of its main principles. There is a famous quotation from Kiyerkegour maintains that: "if something was meant to be written on my tombstone, I would have it be "that person" (Anderson, 2008, p. 69). In fact, this indicates the importance of individualism in the existentialisms' approach. The philosophy of existence claims that philosophy, in fact, begins with individualism, which is completely in interaction with the world and people in it. We, as mortal beings begin philosophy with individualism, not with abstract titles. From the point of view of existentialist philosophers, man is not cognizable through philosophical theories and logical fantasies; but rather is defined by his actions and in experiments. This cognition does not happen as a whole; the knowledge should be gathered by studying man's each and every aspect, part by part. In every philosophical systemization, prior to everything else, man is considered generally, and secondly, it is endeavored to understand him by logical and mental theories. These two are both invalid and unaccepted from the point of view of existentialist philosophers (Wall, 1994, p. 98).

From another perspective, in the pragmatic approach and according to the individualism principles, every single 
person has the right of programming and scheduling their own lives and the right of designing an approach, in alignment with their wants and needs, in addition to answering such needs (Shariatmadari, 2005, p. 25). It is evident that the needs of the pupils and students should be regarded as issues of importance. This attention should be so that it would not pose a danger for their social lives. This happens when each individual tries to act on their own wills and interests. They did not see individuals and society as two separate entities and believed that individuals formed in a society and by it however, it is of importance to know that an innovative individual is a person who builds the social and individual interactions as they are. When there is unity between society and each of its individual members, social reactions are prevented and corrected and it is then the effect of each individual on his or her society and the effect of their society is analyzable. In this approach, but they affect social interactions without insisting on personal interests and desires. In this view towards individualism is rooted in the Russoian method of thought about individualism and the place and importance of each individual in their society. However, it can be said that the Frankfurt approach originates from the thoughts and ideas of Cunt, Diltay, Niche, and John Paul Sartre, who put great emphasis on the individualism factor. The main essence of the Frankfurt doctrine considering the modern society is hidden in the fact that it claims that logic, is in fact logical, whilst the society is not, and this is in addition to its straight forward criticism about the freedom-replenishing and dominant nature of technology. Marcuse (2004) stated that in today's industrial societies, production is a destructive force, which is increased by the moment. Individualism and humanism are in grave danger; the thoughts, fears and hopes of the members of society have become the playthings of the great powers, poverty and poorness show themselves alongside might and prosperity and it is so that the progression and development of such societies seem illogical even in their fundamentals. From the point of view of the criticism doctrine, the modern society is illogical, because the needs and abilities of the individuals, even the individuals themselves, have been violated in one way or another. It is in such a society that even though there is prosperity and services; members who are not able to express, develop their talents and abilities. The freedom of choice amongst different products and services which threaten the social control on life, is no way considered freedom, but is, in fact, supporting alienation. General alienation is a concept which shows the physical and mental separation of the members of a society, in addition to the actual separation from work, occupation and the society. One of Marcuse's (2004) greatest criticisms concerning the modern civilization is the behavior of humans which has become uni-dimensional. Therefore, two of the most important phenomena which lead to this sort of behavior are social media and entertainment products. In addition to these, an educational system which replenishes innovation may be mentioned as well. The result of such a state, in Marcuse's opinion, is depoliticizing the society and the disappearance of political and ethical values from our social lives (Marcuse, 2003, p. 54).

Therefore what is of importance is that in the analytic approach, a close and direct relationship between individualism and socialism is evident, while from the existentialist approach, individualism is known as a completely separate issue from socialism. From the pragmatic point of view, even though individualism is an accepted principle, it is only valid in the domain of society. Nevertheless, from Frankfurt's approach, individualism is considered a main principle in their critical approach towards the social state, which affects the individuality of humans and diminishes an individual's thought and innovation and in other words, deprives man of his individuality.

\section{Tolerating Adversaries or Simplification}

One of the other aspects of liberal humanism is the factor of tolerance and simplification. Simplification is derived from the root simplicity, which means to take something or someone lightly and ignorantly, and to interact with them softly (Dehkhoda, 1994, p. 68). The term toleration is a Latin word, derived from the root tolero, in the meaning of enduring someone or something. It is also synonymous with the word tollo, which means to carry or to permit; it seems that one who tolerates another, bears a weight but in actuality simplification and tolerance are defined as not to restrain another person knowingly or intentionally or to permit thoughts and deeds which are either illogical, or unacceptable (Fathali, 1999, p. 11).

From the point of view, the analytic and existentialist approaches, the aspects of tolerance and simplification are not to be considered as principles of these approaches due to being correspondent to mankind, whilst these two approaches deem humans and humanism as granted. However, in the pragmatic approach, one may define tolerance and simplification as one of the main principles and aspects of this approach. In Rorty's (1998) opinion which is one of the best known modern pragmatists, simplification is relevant in situations where general conclusions and decisions are not made. Therefore, different and opposing opinions should be tolerated. In other words, Rorty (1998, p. 41) claims that "pragmatists define the aim of research as a complexion of willing agreements and simplified and tolerated disagreements.

As one of the main principles of education, simplification indicates that the relationship between the tutor and 
pupil should be regulated so even if a common agreement is not achieved, different opinions should be honored, tolerated and disagreed with simultaneously. The creation of such endurance should be determined as one of the most important principles in the regulation of class relationships. Rorty only accepts simplification in the form which is found inside societies. In other words, toleration of only those who are a member of a society which Rorty has described and those who have accepted its regulations is relevant. However, about those who are not part of this society and are not bound by such regulations, tolerance and simplification is completely irrelevant. As a result he claims that if parents who are religious or oppose homosexuals or are racist, ask an educational center to avoid teaching their children specific books which are in opposition with their points of view and their lifestyle, their request will not be heeded. He addresses them with this sentence "You should be taught with this aim and with these regulations." (Rorty, 2002, p. 22).

Rorty tries to do the same thing to philosophy that once philosophy did to religion. In fact, as Ralls claims, the time has approached to privilege from tolerance and simplification in accordance with philosophy itself (Rorty, 2006, p. 25). In Rorty's opinion, ignorance, arrogance, and sarcasm are not always in opposition with ethics and that we should abandon the habit of taking everything so seriously. In his opinion, "it is difficult to both be enchanted by an illustration of the creation and to tolerate every other illustration in existence at the same time" (Rorty, 2006, p. 25).

From another aspect, Frankfurt's approach criticizes tolerance and simplification. In Marcuse's (2004) opinion, the starting point of political progression is to imagine two different levels of social life: 1) The level of unrealistic, untrue, and daily needs and wants and 2) The level of true historical desires and needs. In his opinion, the workers who were supposed to be the represents of these actual desires were no longer able to determine their own desires. The worker society and in general, the entire society have been drowned in the fake and unrealistic desires provided by the society of investors and producers and feel happy and content about being so. In Marcuse's opinion, knowledge of the actual needs is in fact subconscious; one that Froyd has explained too. In other words, the actual desires and needs of humans exist in his subconscious and until they have not become part of one's conscience, any type of revolution is actually impossible. The systemization of capitalization acts in a way to replace such original and authentic needs with those which are fake. In one of his articles concerning with tolerance in today's modern industrial societies, Marcuse (2004) has asserted that the tolerance which exists in such societies as fake and bewitching which in fact is a suppressor of real freedom and liberty. Expression of opposing ideas is free in such societies, but these opinions, expressed or unexpressed, have no influence on the ruling and prevailing dominance. In addition, members of today's societies even the democratic ones, have no actual liberty and the options to peruse are in fact no different from each other making the criticism of such societies improbable. The freedom of speech is in fact an aid in helping the continuity of such dominances, due to its giving relevance to ideologies which are ruling the society. In addition, modern society is rough towards true criticism and does not tolerate it and even crushes the slightest possibility of any other form of society being proposed to it by its members. In the same stance as the explanations given, it is important to note that in analytic and existentialism approaches, tolerance and simplification have not been considered, since it is in a way, a movement towards relativity. Whilst in the pragmatic approach, tolerance and simplification are accepted as main principles which are considered relevant for the members of that society and irrelevant for those who are not. In Frankfurt's approach, tolerance is not considered a principle, since it is believed to be a factor leading towards the dominance of the ideologies which are already ruling the society and also the reason that freedom of speech is of no effect against the ruling dominance.

\section{The Dominance of Regulations or Legalism}

The basis of regulation, in the ideology of liberal humanism, is equal to natural rights and the regulations corresponding to it. The natural rights of each person are defined by the three factors of the right to live, the right to be free and the right to possess. They have been funded on the ideas of John Locke and are the representation of these ideas in societies and in politics. In addition to the regulations which are set for each society, these laws form the basis of all the regulations in each society. The principle of legalism is defined so that the main value for declaring these deeds and behaviors as regulations are decisions and actions. In addition, no organization or individual, wither governmental, either non-governmental, is not capable or allowed to surpass such regulations.

The issue of legalism or legal domination stated in the analytic and existentialism doctrines is not presented as a principle; in the analytic approach, the factors of responsibility and the right of free choice are considered, which means that individuals choose from the options that are available and take the responsibility of their choice as well. Therefore, the method and lifestyle that an individual chooses form the regulations which are set. In the existentialism approach, due to the belief that man is fated or doomed to be free and that he should build his own world, it is his decisions which determine the regulations ruling a society, which in actuality, take a personal 
form to themselves. Therefore, there are no regulations known as general, social, or public regulations, as in these two approaches.

An overview of the pragmatic approach indicates that this doctrine is in the search of the results of the actions which are performed; if an ideology or an action is useful and if its results are positive, that ideology is accepted, otherwise it is rendered obsolete. In general, passing from uncivilized and natural is defined as social regulations. The aspects of security, the right to live, the right to possess and freedom, general will, socialization and its counterpart, have been studied and assessed in this field. From this approach and by reviewing different ideas of ideologists such from Haber to Cunt, important information may be derived and put to use on the subject of the conceptual progress of such regulations and their societies (Telis, 2006, p. 277).

Frankfurt's viewpoint upon the issue of legalism is one with criticism, since most of the followers of this doctrine believe that the enlightening has not yet reached its end. By relying upon Webry's definition of modern logic which emphasized the use of instrumental logic, Adoreno and Horkyymer, two of the main establishers of this doctrine, eventually achieved passivism towards the achievement of these prospects. However, Habermass chose a different path and in opposition to them, believing that there are potentials in the enlightening already performed which may be used and extended to reach the prospects which were earlier mentioned. He does so by criticizing Webry's approach on modern logic and more significantly, by determining instrumental logic as the only form of modern logic which must be pursued. For this means, he approached Weber's definition of modern logic which he had provided as a result of a theorem which concerned the relationship between social interactions and instrumental interaction. Habermass declares this definition incomplete and criticizes it. In his famous book, the RELATIONAL INTERACTION THEORY, he applies to determine and identify the different forms of social interactions, and as a result, introduces one, which is known as the relational interaction, that he believes has been unconsidered and left unattended in the related studies. Relying on relational interaction, he provides an explanation for logic, which he named interactional logic.

Habermass then proceeds to study two groups of a society which represent either forms of the interactions mentioned. The group which corresponded with instrumental logic was named the system, and that which did so with relational logic was named the living world. In the modern ages, due to the progression of instrumental logic and the beginning of its influence on the different aspects of the society, slowly but surely, the living world which is based on understanding, will be overpowered by the former logic which does not have such a basis. Habermass deems the role of regulations in the modern society necessary to prevent such dominance over the living world and relational logic by instrumental logic which will result in the complete depletion of interactions, dialogues, thoughts, and opinions. Regulations bear responsibility due to the reason that the previous causes which held the society together and caused its unity (such as metaphysical and religious approaches) are no longer able to fulfill their duties, therefore, this burden is to be carried by the social regulations which are to be set. With relying on these sociological fundamentals, Habermass aims to study the legal theorem and to present a theorem about the regulations which are accepted in modern societies. He accepts a regulation as legitimate that guarantees the individual and social rights of the members of the societies in addition to being compatible with the basis of the argument which he himself has proposed. By analyzing different traditional political philosophies and he concludes that all of the previous regulations were incomplete considering the different aspects of the individual or social rights of individuals. Therefore, he proposes a set of regulations which compensate for their lack of coverage. In addition, regulations and democracy are in conceptual alignment with each other. Repairing and renovating the relationship between democracy and regulation is one of the main issues that Habermass has attended to in his book Amongst the Realities and Norms.

Corresponding to the information provided above, the issue that is of importance is that the analytic and existentialist approaches do not consider the dominance of regulations and laws. In other words, self-righteousness is generalized and accepted. While in the pragmatic approach regulations are action oriented. In other words, a regulation is only considered legitimate if it is a result of some action or deed or in other words, is of functionality. However, in the Frankfurt doctrine, the combination and complexion of individual and social rights are of importance, in a way that the members of the society are able to live with each other and under the Influence of Relational Coexistence.

\section{The Dominance of Logic and Science}

In liberalism, human is known as a naturally intelligent being. Rationalists approach science due to its being an illuminator and an enlightener, and consider it as a guide which leads to one's self (Shapiro, 2001, p. 8). The biggest emphasis of the liberal philosophers is concerned nature. In their opinion, nature is the source of justice, virtue, and benevolence (Shapiro, 2001, p. 14). They believe that humans are good by nature and if they act 
accordingly with their logic, they will be successful. In their opinion, the natural behavior of man is him being logical and acting so. The result of such a discussion was the exclusion of religion and faith, which are defined in opposition with logic. In actuality, liberalism is one of the main aspects of the secular doctrine and in a way is known to be in alignment with the prospects of the age of enlightenment. Therefore, the liberal philosophers have extended the assumptions of the secular doctrine in all of the aspects of liberalism. For example, in his endeavors to find a definition for logical ethics, Cunt separated ethics from religion, since he believed that ethics are not forced to us by an external force or person and that no human is in need of metaphysical guidance. He rejected all forms of the heavenly religions since he did not deem them necessary for human progression (Shapiro, 2001, p. 18). Other liberals also believed that man is intelligent by nature. However, they did not claim that man is always intelligent and logical, but rather that he has the ability to be so. They believed in the existence of objective truth and by relying upon examinations and experiments, tried to discover it and prove its existence. Achieving the truth is needless of a religious basis, revelation and evidence. Employing logic to distinguish correct from incorrect is enough. From this aspect, whatever that does not pass the logical tests set by the mind, are rejected and rendered as obsolete, and the greatness or the power of what lies within or behind it is of no importance (same source, p. 27).

From another aspect, with an overview of the concept of humanism in the modern age, one may conclude that in the west, modern humanism was given birth to by pragmatism. Modern humanism values the importance of modern science very much. The theories, basics, and the discoveries achieved are accepted by humanism, values subjects such as biology, psychology and social sciences very much due to their being close relationship with the welfare of humans. In addition, humanism does not regard science as the actual version of the truth, but actually sees it as a creation of man which he has made in order to aid himself in discovering the truths. Since the final judgment and the definition of correction or truth has been bestowed upon man's experience, the classic differentiation made based on issues or being either sacred or not, were diminished. Humanitarians believe that though phrases such as sacred, holy, religious and truth are not authentic, they do contain theoretical or scientific values and are, therefore are of importance to humans (according to the basics of pragmatism).

Modern American humanism accepts the logic proposed by the pragmatic doctrine as well. The nature of human is his logic; therefore, each human possesses logic in one form or another, and due to this, he makes his own world and fate. But logic should be nourished and developed so that it will be better able to guide man in his path. As John Dioyi has stated, it is with the progression of logic that man is able to extend the boundaries of knowledge and science. Therefore, logic is the product of a progressive procedure. In any way, it is logic that makes man what he is and gives him a superior position amongst the other beings in nature. Rorty claims that similar to other animals, man is a sensitive being which reacts to the changes in his environment. The main difference between man and animals is in the complexity of this reaction and sensitivity. Therefore from Rorty's perspective, the increase of man's science or knowledge is not due to increases in the depth or height of his understanding, but is actually the increase in the dimensions of a cover which he has created in order to align and adjust himself better with the environment around him, either it being his natural environment or his social environment (Gaetti, 2002).

By taking a glimpse on Frankfurt's approach, one may claim that in this approach and with bearing in mind the gap that most of the works, which were completed by the followers of this doctrine, cause between it and the Marxist movement, the attendance to common issues and significant similarities between the deep passivism of Max Weber's sociology, especially in the field of opposition against the process of rationalization of the modern societies and the general criticism of the Bourgeois culture and the intellectual ideologies presented by Horkyymer, Adonezo, and Marcuse, as the main essence and element of the critical theory are noticeable. Therefore, between the thought of the technical dominance of logic and Max Weber's assumption concerning the procedure of achieving logic in the modern world, a great similarity is evident and due to this, the followers of the Frankfurt doctrine are under an increasing influence of the ideas of Max Weber. This influence is so much that some philosophers refer to the period between the years 1950 and 1960 as a phase of passing from Marx to Weber's ideology. This is due to historical tendencies hidden in the developed industrial societies. Technical logic is considered one of the abstract forces which shape the society, which is not under the control of man and without the presence of specific social persons or groups. Without taking the general shape and state of the society into consideration, for instance that being based on socialism or capitalism, being totalistic or democratic, the society should pursue its programs and accomplish its tasks.

Another similarity between the ideologies of Weber and the Frankfurt doctrine may be found in the passivism related to their descriptions and explanations of the modern industrialized society; in Weber's opinion, the somewhat constant extension and progression of achieving logic means that the society proceeds towards the 
dominance of total instrumental social relationships. These relationships are similar to an iron cage or a mechanized stone age which prevents individual innovation. In Weber's opinion, there is no effective defense against such a threat, but a doomed and hopeless endeavor to preserve some of the more personal values and the possible rise of a charismatic leader who is capable of setting man's and the society's life in a new path. In his opinion, the main concept of modernization believes in one's self and logic.

This concept has become dominant in the lives of the people living in the modern contemporary age. The human interactions have proceeded towards calculable, quantitative, and instrumental regulations and therefore, the progression of science has become possible by ignoring philosophy; this issue is in need of the distancing all that is illogical and unpredictable, and even mysterious, from man. Weber has chosen to name this as "the charm depletion". Weber persists on the fact that religion or the protestant behavior has accepted this attracts depletion in the procedure of development when opposed to modern capitalism. Therefore, many of the protestant behaviors have become accustomed to the capitalism system which is dominant. Therefore, the rationalization behavior formed the economic and social basis of today's societies, and shaped the logical production systemization and therefore, dominated over the highest and lowest members of each society which is formed by families and even the educational units.

Nevertheless, the dominance of logic was not the promised freedom and liberty. The hopes and dreams of the philosophers of the enlightening age turned out to be wrong and futile. Those who saw the progression and development of man in the need of scientific logic and technology saw it to take a completely different course. Instead of liberating man, they led to the dominance of instrumental logic and more control over different aspects of the lives of members of the society. Adoreno and Horkhymer continued to criticize Weber's instrumental logic, but never accepted that instrumental logic, which was the output of the enlightening age, is the correct way of logic. In their opinion, this fake and unreal knowledge is based on a critical belief of knowledge. They believe that this logical belief once wanted to free men, burn traditions, and oppose them in endless arguments. However, they themselves became the funders of new traditions which, in the end, resulted in a more solid and resolute form of dominance because it instrumental logic denies the independence of all phenomena for the benefit from an unreal, self-manifested and ideological generalization. It was so that Horkhymer and Adoreno persist on the self-destructiveness of enlightenment and logic in the modern age. Reducing primary logical belief in instrumental logic and the dominance over nature have had many inhumane results and have ended in the slavery of man in the bounds of capitalism. Adoreno and Horkhymer introduce fascism, which is the main provider and background for fantasizing and illogical thought, as a part of the instrumental logical procedure in the contemporary age. In their opinion, the formation of a suppressing and destructive society which diminishes all hope of freedom is the result of the forces which were active in the enlightening age. Fascism, as the upmost advance of the modern society, is not a historical accident or unintended occurrence. In other words, fascism is not against modernization, but it is its natural successor. The forces of the enlightening age, which gain more power by the increase of the dominance of logic over nature, will produce self-destructive forces in their highest pint of progression which will appear as the forces of fascism.

Due to the explanations provided, it can be concluded that the pragmatic view about logic and rationalization is that of an instrumental logic, whilst the approach that the Frankfurt doctrine has is a combination of both instrumental and nature-based logic.

\section{Conclusion}

Liberalists believe that man has been born free and possesses the freedom to choose and the will to do so as well as being permitted to improve himself as much as possible in a free and liberal way. Therefore, liberalism may be known as the doctrine or philosophy of freedom. The term liberalism was first used by Claud Boast, but the ideological movement which is known by this title is older than the age mentioned; one can even say that it is as old as the fights and arguments which are related to man's freedom throughout time. Nevertheless, liberalism, in the modern and contemporary form, is the result of modern humanism and individualism, and has originated from the age of renaissance and the religion justification movement.

As it is evident from the title of the article, the main purpose of this research was to study liberal humanism and its effect on today's educational aspects and perspectives. Therefore, in the beginning it was endeavored to explain the definitions of humanism and liberal educational aspects and then the history of liberalism and liberal education were presented. Following that, the concept of humanism was explained and in the end, the relationship between contemporary educational aspects with those of the liberal humanism was determined.

As implied by the studies and concerning the effect of liberal humanism on the modern educational perspectives, 
it may be concluded that a relationship does exist between these two factors and they accompany each other in some of the common aspects and factors. However, the different prospects of liberalism varied with each other, depending on which doctrine or approach.

In the existentialism doctrine, the method of examining liberation is based on individual authenticity. In the pragmatic ideology, the result of human actions is set as a value for all issues and deeds, and in the Frankfurt's doctrine, which tends to criticize the modern society, the limitations forced on man from the modern society are concerned. With a review of Frankfurt's critical approach, it can be stated that the critical approach is a reflection of the ethical and epistemological overviews which insists on: 1) The preservation of beliefs, not by force; 2) Skepticism concerning all beliefs; 3) The belief that knowledge and understanding are difficult, but not impossible, issues 4) The freedom of thought; 5) Honesty; and 6.Tolerance. The pragmatic approach insists on 1) Dependency on situation; 2) Relativity of epistemology; 3) Indirection of epistemology; 4) The probability of gnosis; and 5) The theoretical nature of gnosis. In addition to the mentioned issues, the existentialism approach insists on: 1) Paying attention to the actual concept of an individual instead of a theoretical and mental assumption and criticism towards the inhumane nature of the industrial age. 2) Identification of the bad and unacceptable state of the man, 3) Belief in the highest existence; 4) Identification of freedom and responsibility; and 5) The weakness and insecurity of man.

\section{References}

Anderson, S. L. (2008). Philosophy of Ki YerKegor (Translated by Deyheymi, K.). Tehran: Tarh e No Publications.

Berlin, A. (2001). Four articles concerning freedom (Translated by Movahhed, M. A.). Tehran: Kharazmi Publications.

Brady, B., \& Owen, D. (2009). Pupils as six excluded for Taking knives into school Independent is feb.

Bring, R. (2008). The common school. In M. Halstend, \& G. Haulon (Eds.), The common school and The comprehensive I deal: A defence by Richard Pring with complementary essay (pp. 1-19). Oxford: Wiley.

Clark, L. (2008). 2200 pupils sent home every day as violent Behaviour in class reaches record levels. Daily Mail, June 24th.

Coates, S. (2009). Inner city violence is taking us to the wire, say Tories. The Times, August 25 th.

Curriculum Development Center. (2007). Introduction to the political and ideological doctrines. Tehran: Samt.

Dehkhoda, A. (1994). Dictionary. Tehran: Soroush Publications.

Fathali, M. (1999). Tolerance and simplification. Qom: Taha cultural center.

Gattei, S. (2002). The Ethical Nature of Karl Popper's Solution to the Problem of Rationality. Philosophy of the Social Sciences, 32(2), 240-266. http://dx.doi.org/10.1177/004931032002006

Gosling, J. C. B. (1973). Plato. London: Routledge.

Guteg, G. (2007). Philosophical doctrines and educational ideologies (Translated by Pakseresht, M. J., 4th ed.). Tehran: Samt.

Hirst, P. H. (1965). Liberal education and the nature of Knowledge. Landon: Routedge and Kegan paul.

Lapsley, D. H. (1988). Self, ego and identity. Integrative Verlag Inc.

Marcouse, H. (2003). Uni-dimensional man (Translated by Moayedu, M.). Tehran: Amir Kabir.

Meiksins, W. E. (1972). Mind and Politics: An Approach to the Meaning of Liberal and Socialist Individualism. University of California Press.

Muir, J. (2005). Is our history of educational philosophy mostly wrong? The Case of Isocrates. Theory and Research in Education, 3(2), 165-195. http://dx.doi.org/10.1177/1477878505053300

Paton, G. (2004). Labour's school reforms have destroyed English, says ATL head Mary Bousted. Telegraph, 4 Apr.

Paton, G. (2009). Thousands of pupils “drop out of school at 14”. Telegraph, 23 February.

Pring, R. (2009). Education for all. All futures of educational and Training for 14-19 years old. London \& N-C Rontledge.

Project on Liberal Education and the Sciences. (1990). The Liberal Art of Science: Agenda for Action. Washington, DC: American Association for the Advancement of Science. 
Rorty, R. (1998). Objectivity, Relativism and Truth: Philosophical Papers I. Cambridge: Cambridge University Press.

Rorty, R. (2002). Universality and Truth. In R. B. Brandom (Ed.), Rorty and His Critics. Oxford: Blackwell Publish.

Rorty, R. (2006). The priority of democracy over philosophy (2nd ed.). Tehran: Tarh e No.

Sartre, J. P. (1947). Existentialism and Human Emotions (Trans. by Bernard Frechtman). New York: Philosophical Library.

Shariatmadari, A. (2005). The principals of philosophy and education (Vol. 19). Tehran: Amir Kabir.

Shipro, J. S. (2001). Liberalism, definition and history (Translated by Hanai Kashani, M. S.). Tehran: Markaz publications.

Thelis, R. B. (2006). Ralz philosophy (Translated by Deyhaymi, K.). Tehran: Tarh e No Puublication.

Ulich, R. (1968). History of Educational thought. New York. American Book Company.

Wall, J. A. (1994). Phenomenology and the philosophy of existence (Translated by Mahdavi, Y.). Tehran: KH publications.

Walzer, M. (1995). The communication critique of liberalism, published in new communication thinking. University of Virginia.

Zibakalam, M. (1993). Liberal education, Its Classical and Development in Islamic and Modern Western Tradition (PhD thesis, Bradford University).

\section{Copyrights}

Copyright for this article is retained by the author(s), with first publication rights granted to the journal.

This is an open-access article distributed under the terms and conditions of the Creative Commons Attribution license (http://creativecommons.org/licenses/by/3.0/). 